\title{
Macroprudential Policy: Resolution and Continued Challenges
}

\author{
Igor M Tomic $^{1} \&$ John Angelidis ${ }^{1}$ \\ ${ }^{1}$ St. John's University, New York, United States \\ Correspondence: Igor M Tomic, Peter J. Tobin College of Business, St. John's University, Queens, NY 11439, \\ United States.
}

Received: August 24, 2018

Accepted: September 12, 2018

Online Published: September 16, 2018

doi:10.5430/ijfr.v9n4p43

URL: https://doi.org/10.5430/ijfr.v9n4p43

\begin{abstract}
In this paper we address three issues; 1) The importance of knowing the exact damage caused by a failing firm, as that knowledge assists in creating more efficient policy responses. The failure of a large and complex financial firm, Lehman Brothers, experienced a very difficult and lengthy process in its resolution; the damage was much greater than expected, leading to a change in policies and specifically to a requirement for stress tests; 2) Macroprudential policies are very helpful as the can address issues in a specific sector, something that monetary policy is not designed for. This means that monetary policy designed to bring output and price stability, when combined with macroprudential tools, provides more financial stability; 3) Although macroprudential policies have stabilized the financial industry, some threats remain and therefore several threats are explored.
\end{abstract}

Keywords: asset-price bubbles, financial stability, failure of a large and complex financial firm

\section{Introduction}

Any recession will lead to reexamination of events that led to it: Are there any new facts that need to be investigated, and possibly are new policies needed to avoid a similar recession in the future? Similarly, after the Great Recession there was a need to identify and collect important data on newly identified issues, e.g. those underlying systemic risk. This led to the creation of the Office of Financial Research to make sure that some important data is not "out of view" of the regulators and overall that more information is available to the public. Preventing a deep recession will likely require policy changes as well, as was the case after the 2008-2009 recession.

Not only could there be a need for new facts to understand a recession, but the quality of measurement of known facts, if improved, would be useful. Alfred Marshal was one of the first economists who took careful notes when visiting a factory with respect to the type of activity, wages, etc. Instead of knowing that most workers have subsistence wages, as generally believed, he knew exactly what they were, and found that wages of those who are more engaged in their work were actually rising; a fact not know by his peers. Correct measurement shed light on facts unseen by many. Often, we make general statements that are basically true, but not adequate enough for someone to form a policy. For example, we all agree that if a firm shuts down, it has a negative effect on employment and firm's suppliers, in addition to the shareholders. However, if we knew the magnitude of the impact, it would be easier to assess if some preventive measure is possible (and adequate), for the problem is measured and thus a policy response can be more effective.

One objective of this paper is to show that it was important to understand the full scale and scope of the Lehman Brothers' bankruptcy. Troubled financial institutions are usually merged with the assistance of regulators, masking the full impact of a failing financial firm. The measured impact of the failure of Lehman Brothers showed that the damage of a large and complex failing firm in a stressed economy is larger than anticipated. It is very challenging and inefficient to establish a policy tool to stabilize the banking system without knowing the total damage done as a result of a firm's failure.

The second objective is to point out that the new macroprudential policies had an interesting side effect. By setting policies that promote financial stability, the role of monetary policy become easier. Monetary policy could not address asset-price increases, and formation of an asset price bubble in a specific sector. Now with the macroprudential policy this is possible, as there are tools that can effectively tame asset-price bubbles in one sector. 
The third objective of this paper is to evaluate the performance of the new macroprudential tools to date and point to some possible issues remaining that may pose a continuing threat to financial stability. While macroprudential tools have improved financial stability, some threats to it still exist especially in stressful economic times.

The importance of this paper consists of several items: It reminds us that it is impossible to construct a solid policy unless we can measure the problem it needs to address. We could agree that great policies also contain some positive externality, as macroprudential policies do by resolving issues where monetary policy's reach is limited. Furthermore, it is important to state that there are still circumstances that present a danger to financial stability, and we point out which situations could present an additional threat to financial stability.

The paper is organized in the following way: 1. Introduction, 2. Understanding the exact damage that a failure of a large complex financial institution can cause. 3. Asset price bubbles and assuring financial stability, 4. Results of current macroprudential policies, continuing and emerging challenges, and 5. Conclusion

\section{Understanding the Exact Damage that a Failure of a Large Complex Financial Institution Can Cause}

Failure of a bank is always seen as damaging to community it serves, be it large or small, and in times when many banks experience financial stress, a failure of one may put extra pressure on the financial system as panic emerges. For that reason, the Federal Reserve has historically intervened in cases of large financial firms' failures by merging the troubled firm with a healthy one, and thus providing banking continuity. Such rescue, when concluded reasonably quickly and reasonably quickly, resolve the issue and prevent potential panic, but mask what the total damage caused by the failure could be. Would it be useful to know the exact damage a failure of a large and complex financial firms can cause?

The almost sudden bankruptcy of Lehman Brothers (Lehman) surprised the market participants at first, but later many realized the extent of the damage that was caused by its failure. The bankruptcy of Lehman Brothers was one of the largest and most complex in history, encompassing over $\$ 1$ trillion worth of creditor claims, four bodies of applicable U.S. laws, and insolvency proceedings that involved over eighty international legal jurisdictions. This was accompanied by the complexity of claims and litigations to follow. What was the impact of the failure of Lehman that challenges difficulties and impact of its bankruptcy:

- The predictability of Lehman's claims settlement procedures were hindered by the novelty of its business and financial structure in the context of bankruptcy cases. Chapter 11 proceedings are based on the application of case law relating to the Bankruptcy Court's prior interpretations of cases. While existing case law provided a useful starting point for Lehman's resolution, the court provided new interpretations of provisions in the Bankruptcy Code. In part, this reflected the prominence of complex financial securities that the bankruptcy court had to analyze, perhaps for the first time.

- The poor planning of the bankruptcy process stands out as being especially costly. In contrast, creditor losses would have been more substantial without the ability of Lehman's U.S. brokerage subsidiary, and subsequently of Barclays, to finance positions through the Federal Reserve's newly provided liquidity facilities.

- Lehman's organizational complexity also resulted in delays. For example, in many instances, Lehman and its counterparties were uncertain of the identity of the specific Lehman subsidiary against which creditors had claims.

- Finally, Lehman's interconnectedness led to delays as creditors of the holding company, Lehman Brothers Holdings Inc. (LBHI), argued in court that they were entitled to a portion of recovery from subsidiary assets (since LBHI had guaranteed some of the subsidiaries' debt).

Later in writing the Dodd -Frank Act the detailed evidence of damage caused by Lehman could not be ignored in formulating future policy. To avoid a lengthy bankruptcy process of a large financial firm that affect many counterparties, Dodd-Frank Act offered one solution: make bankruptcy simple and quicker for large firms by requiring them to have a resolution plan and to be stress tested, to assure their stability in times of financial fragility.

\section{Asset Price Bubbles and Assuring Financial Stability}

The severity of the Great Recession brought challenges to economic thought in two ways:

- How do we address large asset price increase that lead to formation of a bubble, whose collapse are undesirable?

- Are there new tools necessary to assure greater financial stability? 


\subsection{What to Do About Asset-Price Bubbles?}

If an asset bubble is forming, should something be done about it? Prior to the Great Recession the opinion of many scholars was not to intervene and then to clean up after the bubble bursts. That was the view held steady until our recent crisis, even if it was visible that an asset bubble was developing (Cecchetti et al, (2000), Greenspan, (2002); Borio, English, and Filardo (2003); White (2004); Kohn, (2006); and Mishkin, (2008). Some arguments in favor of this policy were difficult to ignore:

- Bubbles are difficult to detect. "Moreover, even if correctly identified, bubbles can be difficult to deflate without imposing significant costs on the economy. The implication is that, instead of leaning against a bubble while it was inflating, it would be better to clean up after it had burst" (Trehan, 2009).

- The standard monetary policy tools may not be satisfactory in leaning against the bubble; monetary policy tools are rather blunt as they affect the entire economy - while the price asset bubble may show up only in one or few sectors. Therefore, increasing interest rates, while it could address a sectors' increase in asset prices, it will likely slow down economic activity.

- An increase in interest rates could be ineffective against a bubble as market participants expect high rates of return from bubble driven assets. Bubbles are a departure from normal conditions and there is no guarantee that normal monetary policies will work in abnormal conditions.

Since monetary policy is unsuited to address asset-price bubbles, a solution needs to be found as asset -price bubbles and their collapse could easily affect other sectors of the economy.

\subsection{What if the Policy of Price and Output Stability Do Not Insure Financial Stability?}

For almost a half century after the Great Depression, the opinion of market observers was that the structure of the banking system was solid enough, and likely not to be a cause of disruptions or recessions. The Federal Reserve's role as a 'lender of last resort' was accepted as an additional stabilizing effect; bringing a level of assurance to the banking system. The accepted doctrine was that the Federal Reserve would assist and support solvent institutions that are able to provide solid collateral. The various shocks to our financial system including the failure of Continental Illinois, the S\&L crisis in the 1980's, followed later by the Latin American crisis, the stock market crashes of 1987 and 2000, and the failure of Long Term Capital, caused concerns but did not disrupt the stability of the financial system. In sum, our financial system was stable enough, meaning that with existing regulatory and monetary tools it was managed reasonable well.

The Great Recession 2008-2009 disclosed vulnerabilities in the financial system which in the past did not seem to be material, and thus little attention was paid to them. The Financial Crisis Inquiry Report (2011) presented a detailed description of the many growing vulnerabilities that existed in the economy before the Great Recession. Other researchers also made a significant contribution to discussing how to address asset bubbles as well as how to assure greater financial stability. A building process began to address vulnerabilities that have either gone unnoticed or were consider to be of small importance. The first significant efforts toward assuring financial stability started with the passage of the Dodd-Frank Act in the US and the Basel III in Europe. For example, the Act created new standards to lower the risk that could arise from the "distress, failure, or ongoing activities of large, interconnected financial institutions."(Dodd-Frank, Section 115) Under the Act, financial institutions that are large (by asset size) should be subject to heightened standards, so that they can weather difficult market condition when they arise.

Hahm et al (2012) asked: What if price and output stability do not insure financial stability? This question means that monetary policy that served the country well for a long time may not be enough to guaranty financial stability. Other measures are necessary to assure financial stability to avoid deep recessions. That means that the work to stabilize the banking system that started in the US with the Dodd-Fran Act and in Europe with the Basel III agreement was especially important: It is not designed to only stabilize large financial institutions, but it aids in prevention of more intense recessions. While there will be recessions in the future, if the banking system is able to operate regardless of economic shocks, it will not be an instrument that fuels the worsening of economics conditions.

What is the meaning of financial stability? Financial stability is defined as (ECB, 2015): "A condition in which the financial system - intermediaries, markets and market infrastructure - can withstand shocks without major disruptions in financial intermediation and in the effective allocation of savings to productive investments." In sum, all financial markets should operate as intended without panics and major distortions. A more specific definition is offered by the Office of Financial Research (2015), one of the new agencies created in response to the Great Recession: "Financial stability occurs when the financial system can provide its six basic functions, even under stress: (1) credit allocation and leverage, (2) maturity transformation, (3) risk transfer, (4) price discovery, (5) liquidity 
provision, and (6) facilitation of payments. Financial stability is not about curbing market volatility, predicting financial shocks, or preventing them. Financial stability is about creating a resilient financial system that can withstand economic shocks by continuing to provide basic financial functions to facilitate economic activity."

Did central banks pay enough attention to financial stability in the past? Historically, central bankers have from time to time discussed financial stability, but it was not generally the highlight of their meetings. Williams (2015) suggested that one reason for a lesser concern with financial stability was that it was viewed as a dangerous distraction; a distraction that could damage the credibility of a central bank in its price stability quest.

The new regulations created after the Great Recession established policy tools aimed to assure financial stability. These new tools are often referred to as macroprudential policy tools and they could be divided into two subgroups:

1. Microprudential tools assure that the balance sheet of an individual institution is robust enough to withstand economic shocks: Holding extra capital of a highly liquid quality, sufficiency confirmed by stress tests, and ensured by living wills. These tools have been focused on very large financial firms and they are designed to limit or reduce the risk-taking by banks to assure financial stability.

2. Sector macroprudential tools focus on countercyclical measures to address industry or sector practices that would assure financial stability: LTV (loan-to-value), LTI (loan-to-income, DTI (debt to income) or other countercyclical measures. These macroprudential tools permit focus on specific problem areas, e.g. parts or sectors of financial services, such as real estate lending, without disturbing other sectors of the economy. They add a flexibility that monetary policy alone does not possess.

All macroprudential tools are designed to limit the possibility of an additional crisis. "This framework would provide incentives to these banking organizations to hold substantially increased levels of high-quality capital as a percentage of their risk-weighted assets," Fed Chair Janet L. Yellen said (Yellen, 2011). "This, in turn, would encourage or require such firms to reduce their systemic footprint and lessen the threat that their failure could pose to overall financial stability as it was intended by a proposal originating from the Basel Committee on Banking Supervision" (Fisher, 2014).

Since the Great Recession the application of macroprudential policies has been on the increase. In 2013, the Reserve Bank of New Zealand imposed higher loan-to-value ratio requirements on mortgage lenders as property prices were rising above their historic norms. This new policy resulted in prices of property leveling off and no harm occurred to the economy. The Bank of England had similar concerns over rising property prices; those were slowed by restricting the size of mortgages relative to borrowers' income. On January 27, 2015, the Central Bank of Ireland announced new mortgage policies that restricted borrowing by introducing loan-to value and loan to income limits. It is noted that these restrictions were all in the mortgage fields, an area where the credit driven bubble certainly formed the feedback loops that that we experienced in the recent financial crisis. This provides clear evidence that when an asset-price bubble is forming, measures that have been successful can be applied.

\section{Results of Current Macroprudential Policies, Continuing and Emerging Challenges}

In this section we will discuss some of the macroprudential tools introduced past the financial crisis and what they achieved so far. We then discuss some continuing and emerging threats to financial stability.

\subsection{Stress Tests}

Dodd-Frank established a stricter supervision of large bank holding companied by requiring a periodic stress test. The stress tests serve to measure the reaction of banks' various capital ratios under a hypothetical set of stressful economic conditions, where liquidity is a critical component of financial conditions. Stress testing is forward looking as it is designed to anticipate rapidly changing risk and business conditions. In sum, stress tests assure that the largest and complex financial institutions can continue activities in times of challenging economic events (Brainard, 2018). The latest report (Press Release, June 2018) shows an improvement over time as the largest banking firms increased their holding of high liquid assets from 12\% of assets in 2011 to $20 \%$ in 2017.

On May 24, 2018, the Economic Growth, Regulatory Relief and Consumer Protection Act became law. It increased the SIFI threshold from $\$ 50 \mathrm{bn}$ to $\$ 250 \mathrm{bn}$, thus providing a regulatory relief for smaller and less complex firms; most regional banks are exempt from stress tests. Yet the Federal Reserve has the authority to apply any prudential standard to any bank with at least $\$ 100 \mathrm{bn}$ in assets and can differentiate among banks based on their capital structure, riskiness, complexity, size, or any other risk-related factors (FRB Press Release, June 2018). This means that at present time only 12 financial firms out of 38 in 2017, will be stress-tested. 


\subsubsection{Potential Challenges}

Stress tests results raised awareness of risk which is important for effective regulation. The recent regulatory change requires that fewer banks need to be stress-tested regularly. This means that a larger number of banks undergo less scrutiny and one wonders if more banks being "out of view" of the regulators may lead to periods where financial ratios could be poorly maintained. At the same time all regulations need to be revised from time to time to see whether they need to be altered as over time their impact may be different from what was intended when instituted.

\subsection{Resolution Planning - Living Wills}

Bank holding companies with assets greater than $\$ 250 \mathrm{bn}$ in assets are required to submit resolution plans to unwind operations in an orderly fashion in the event of bankruptcy. These plans or living wills are submitted to the Federal Reserve and the FDIC. Regulator concerns noted a need for clear identification of unwind procedures to avoid movement of assets among legal entities to allow orderly bankruptcy without legal challenges. The resolvability plans need to change as firm's activities, structure, and risk profile change (FRB Press release, June 2017)

\subsubsection{Potential Challenges}

But there are several difficulties remaining. What if market conditions make it difficult for liquidation to occur? It is still doubtful that more than one SIFI or G-SIB failure can be wound down speedily to stabilize the financial system. Handling the failure of multiple financial institutions would require a large amount of coordinated planning and resources. At present, no activity in this direction exists.

\subsection{Countercyclical Buffer}

The countercyclical capital buffer (CCyB) primary objective is to use a buffer of capital to protect the banking sector from periods of excess aggregate credit growth that raises the system-wide risk.

$\mathrm{CCyB}$, part of Basel III and approved as policy by the FRB, applies to firms with more than $\$ 250 \mathrm{bn}$ in assets, to absorb shocks in declining credit conditions. In turn, when the conditions that caused the application of such buffers change, these buffers would be removed or reduced (FRB, Press Release, 2016). The application of CCyB intended to be gradual, not to be disruptive.

The FRB votes at least once per year to assess whether CCyB are needed. So far, CCyB was not been activated yet in the US.

\subsubsection{Biggest Challenge}

In the US we have no experience in the usage of this policy.

\subsection{Market Structure}

Market structures of firms change over time as they adjust to changing technology, market conditions and therefore change their business models. This could become disruptive to the market functioning efficiently; there is a danger of intensity of concentration leading to an increase in oligopoly power. In case of a solitary provider during times of market stress, a failure of a single provider of an important service intensifies further the existing market disruption, thus worsening market outcomes.

\subsubsection{Potential Challenge: Impact of Concentration}

Examples below require attention as increases in concentration could lead to market disruptions. According to the OFR 2017Annual Report 2017, a lack of substitutability is an aspect of market structure that can pose a threat. For example, the increasing reliance on a single institution for settlement of Treasury securities and related repurchase agreements (repos) is a key vulnerability. An interruption in Treasury settlement services would disrupt the Treasury market and potentially a range of other markets. Until recently there were two firms providing services in the settlements of US Treasury securities and repurchase agreements. For some time that role was played by JP Morgan Chase \& Co, and Bank of New York Mellon Corp. In July 2016, JP Morgan Chase announced it was exiting this business leaving BNY Mellon as the sole provider of this service. Additionally, for triparty repo transactions, an important source of funding for large banks and other financial firms, BNY Mellon will remain the sole operator. In the event of financial stress, BNY Mellon would leave its clients to seek alternative funding sources in disrupted markets, thus creating a liquidity squeeze (OFR, Viewpoint, 2017)

\subsection{Financial Innovation: Needed, Yet Challenging}

Financial innovation occurs to fill a market need; however, they can as well be a challenge to regulators. In thriving markets with a variety of clients and changing environments, the opportunity to innovate exists and technology 
improvements can deliver needed services. Current examples would include the role of fintech and firms so engaged or crypto currencies and regulatory structure for investment vehicles based on such products.

\subsubsection{Emerging Challenges: Regulatory Response}

Innovations impose challenges on regulators from various perspectives. Masking intentions: Some innovation may encourage movements of assets from a regulated market to a less-well understood market - or to unregulated institutions and thus 'out of view'. Valid assessment of risk: New products that have a limited performance history make it difficult to evaluate whether the lenders have assessed risk appropriately, further challenging actions or reactions by regulators. The last question that may appear in stressful times: Is there a will of regulators to act when necessary?

\section{Conclusion}

The failure of Lehman Brothers shed a light on the damage that the failure of a large and interconnected firm with a variety of complex products could produce - and especially when it happens in an environment of high economic stress. The resolution of Lehman Brothers involved court cases in 30 international jurisdictions that took a very long time to resolve, and the damage from the failure was much greater than anticipated. This experience and knowledge had a sobering effect on those involved with identifying appropriate policy tools formed afterwards. This can be seen from some of the macroprudential policy responses including the imposition of living wills or resolution plans for large financial firms, to clarify the burden in the event of liquidation.

The benefit of the new macroprudential policies have provided tools that can also address the situation where asset prices rise and begin to form a bubble. As used in other countries, specific micro-prudential policies, for example, have been used to restrict credit, slow the formation of an asset bubble and slowly stabilize prices. This was a great news to those in charge of monetary policy, for it is too cumbersome to address the issue especially if it shows up in one sector of the economy. The result is that monetary policy has a new partner, macroprudential policy, which is flexible enough to address asset-price bubbles in a single sector without disrupting the economy in general. That means monetary policy can continue to pursue output and price stability, and macroprudential policies can help assure financial stability.

The imposition of financial stability tools by the Dodd-Frank Act, and Basel III in Europe, did add to financial stability as intended. So far so good. However, some threats to financial stability remain; while not necessarily large threats, but in an economy under stress these threats are still disruptive. What can cause potential disruptions? Limited experience with countercyclical buffers and their application; impact of concentration and monopoly power in certain parts of the financial markets; innovation may encourage the movement of activities from regulated markets to unregulated ones where it may be hiding from regulators domain as "out of view".

New regulations that recently modified the Dodd-Frank Act eased the regulatory burden for smaller financial institutions which is consistent with the need to review regulation ex poste to understand unintended consequences. However, when regulations are eased, one is concerned regarding their consequences over time. One should not forget the warning contained in the Financial Crisis Inquiry Report: "The crisis was avoidable - a result of human action, inaction, and misjudgment.... the greatest tragedy would be to accept the refrain that no-one could have seen this coming, and that nothing could have been done.... as it may happen again".

\section{References}

Acemoglu, D., Malekian, A., \& Ozdaglar, A. (2013). Network security and Contagion. NBER, Working Paper, No. 19174.

Akinci, O., \& Olmstead-Rumsey, J. (2015). How Effective are Macroprudential Policies? An Empirical Investigation. Federal Reserve Board. International Finance Discussion Papers 1136. Bank of Canada.

Appelbaum, B. (2015, October). Skepticism Prevails on Preventing Crisis. NYT, B1.

Bernanke, B. S. (2009, March 10). Financial Reform to Address Systemic Risk. Speech at the Council on Foreign Relations. Retrieved from http://www.federalreserve.gov/newsevents/speech/bernanke20090310a.htm

Bernanke, B. S., \& Gertler, M. (2001, May). Should Central Banks Respond to Movements in Asset Prices?. American Economic Review, 91, 253-57. https://doi.org/10.1257/aer.91.2.253

Board of Governors of the Federal Reserve System and the Federal Deposit Insurance Corporation. (2017, December 19). Agencies announce joint determination for loving wills, Joint Press. 
Board of Governors of the Federal Reserve System. (2018, April 5). Proposed rule regarding the stress buffer requirements.

Borio, C., English, W. B., \& Filardo, A. J. (2003, February). A Tale of two Perspectives: Old or New Challenges for Monetary Policy?. BIS Working Paper 114, Basel: Bank for International Settlements.

Brainard, L. (2018, April 19). Safeguarding Financial Resilience through the Cycle. Speech at the Global Finance Forum, Washington, DC.

Cecchetti, S., Genberg, H., Lipsky, J., \& Wadhwani, S. (2000, July). Asset Prices and Central Bank Policy. Geneva Report on World Economy No. 2, London: Centre for Economic Policy Research.

Central Bank of Ireland. (2015, January). Informational Note: Restrictions on Residential Mortgage Lending.

Cerutti, E., Claessens, S., \& Laeven, L. (2015). The Use and Effectiveness of Macroprudential Policies: New Evidence. IMF Working Paper No. 2015/61. https://doi.org/10.5089/9781498321051.001

Claessens, S., Kose, M. A., \& Terrones, M. E. (2014). The global Financial Crisis: How Similar? How Different? How Costly?. In Claessens, S., Kose, M. A., Laeven, L., \& Valencia, F. (Eds.), Financial Crisis: Causes, Consequences, and Policy Responses, International Monetary Fund.

Cunningham, R., \& Friedrich, C. (2016, July). The Role of Central Banks in Promoting Financial Stability: An International Perspective. Bank of Canada Staff Discussion Paper 2016-15, Bank of Canada.

Dell-Ariccia, G., Igan, D., Laeven, L., \& Tong, H. (2014). Policies for Macro-Financial Stability: Dealing with Credit Booms and Busts. In Claessens, S., Kose, M. A., Laeven, L., \& Valencia, F. (Eds.), Financial Crisis: Causes, Consequences, and Policy Responses, International Monetary Fund.

European Central Bank. (2017, May). Financial Stability Review.

Federal Advisory Council and Board of Governors. (2015, December 4). Minutes of Meeting on Friday.

Financial Crisis Inquiry Commission. (2011). Financial Crisis Inquiry Report. Public Affairs, New York.

Financial Stability Oversight Council. (2016, September. 22). Annual Report.

Financial Stability Oversight Council. (2017, December 14). Annual Report.

Fisher, S. (2014). Financial Sector reform: How Far Are We. NBER Reporter, No. 3.

Fisher, S. (2015, March 30). Nonbank Financial Intermediaries, Financial Stability, and the Road Forward. Remarks at $20^{\text {th }}$ Annual Financial Markets Conference, FRB Atlanta.

Fleming, M., \& Sarkar, A. (2014, March). The Failure Resolution of Lehman Brothers. Economic Policy Review, 20(2), 28-29, Federal Reserve Bank of New York.

Gerardi, K., Lehnert, A., Sherlund, S. M., \& Willen, P. (2008). Making Sense of the Subprime Crisis. Brookings Papers on Economic Activity, Fall, 69-160. Retrieved from http://www.brookings.edu/economics/bpea/bpea_conferencepapers_fall2008.aspx

Glaeser, E. L., Gyourko, J., \& Saiz, A. (2008). Housing supply and housing bubbles. Journal of Urban Economics, 64(2), 198-217. https://doi.org/10.1016/j.jue.2008.07.007

Greenspan, A. (2002). Opening Remarks, "Rethinking Stabilization Policy. Federal Reserve Bank of Kansas City Economic Symposium, 1-10.

Hahm, J.-H., Mishlin, F. S., Shin, H. S., \& Shin, K. (2012). Macroprudential Policies in Open Emerging Economies. NBER working paper 17780. Retrieved from http://www.nber.org/papers/w17780

Hendershott, P., Hendershott, R., \& Shilling, J. (2010). The mortgage finance bubble: Causes and corrections. Journal of Housing Research, 19(1), 1-16.

International Monetary Fund. (2017, October). Global Financial Stability Report.

Jain, C. L., \& Tomic, I. M. (1995). Essentials of Monetary and Fiscal Economics. Graceway Publishing Company, New York.

Jeanne, O., \& Korinek, A. (2014, April). Macroprudential Policy beyond Banking Regulation. Banque de France, Financial Stability Review, No.18.

Jorda, O., Schularic, M., \& Taylor, A. M. (2012, October). When Credit Bites Back: Leverage, Business Cycles, and Crisis, FRB San Francisco. Working Paper Series, WP 2011-27. 
Keeley, B., \& Love, P. (2010). From Crisis to Recovery: The Causes, Course and Consequences of the Great Recession. OECD Insights, OECD. https://doi.org/10.1787/9789264077072-en

Keeley, B., \& Love, P. (2011). From Crisis to Recovery: The Causes, Course and Consequences of the Great Recession. OECD Insights, OECD, Paris.

Kindelberger, C. P. (1978). Manias, Panics, and Crashes: A History of Financial Crisis. New York: Basic Books. https://doi.org/10.1007/978-1-349-04338-5

Kohn, D. (2006, March 16). Monetary Policy and Asset Prices. A speech delivered at a Colloquium of the European Central Bank, Frankfurt.

Mishkin, F. S. (2008, July 28). Wither Federal Reserve Communication. A speech at the Peterson Institute for International Economics, Washington, DC.

Mishkin, F. S. (2010, June). Monetary Policy Flexibi8lity, Risk Management, and Financial Disruptions. Journal of Asian Economics, 242-246. https://doi.org/10.1016/j.asieco.2009.07.005

Office of Financial Research. (2014). Annual Report.

Office of Financial Research. (2015). Annual Report.

Office of Financial Research. (2017). Annual Report.

Office of Financial Research. (2017, October 26). OFR Viewpoint, 17-04.

Press Release, \& Federal Reserve Bank. (2016, September 8). Federal Reserve Bank approves final policy Statement detailing framework for Setting Countercyclical Capital Buffer.

Press Release, \& Federal Reserve Bank. (2017, June). Dodd-Frank Act Stress Test 2017: Supervisory Stress Test Methodology and Results.

Press Release, \& Federal Reserve Bank. (2018, June 21). Federal Reserve Board releases results of supervisory bank stress test.

Press Release, \& Federal Reserve Board. (2018, April 19). Seeks comment on proposal to simplify capital rules for large banks.

Reinhart, C., M., \& Rainhart, V. R. (2010). After the Fall. Federal Reserve Bank of Kansas City Economic Symposium - Macroeconomic Challenges: The Decade Ahead. Retrieved from http://www.kansascityfed.org/publication/sympos/2010/reinhart-paper.pdf

Reinhart, C., M., \& Rogoff, K. S. (2009). This time is Different: Eight Centuries of Financial Folly. Princeton, NJ: Princeton University Press.

Stiglitz, J. E. (2010). Interpreting the Causes of the Great Recession of 2008. Retrieved from Gsb.columbia.edu

Svensson, L. E. O. (2014). Inflation Targeting and 'Leaning against the Wind. International Journal of Central Banking, 10(2), 103-114.

Trehan, B. (2009, September 21). Part 1: Do Coming Crisis Cast their Shadow Before?. Federal Reserve Bank San Francisco, Economic Letter.

US Government Accountability Office, GAO Highlights. (2015, June). Bank Regulation: Lessons Learned and a Framework for Monitoring Emerging Risks and Regulatory Response.

White, W. (2004, October 26). Making Macroprudential Concerns Operational. Speech delivered at a Financial Stability Symposium organized by the Netherlands Bank, Amsterdam. Retrieved from www.bis.org/speeches/sp041026.htm

William, J. C. (2015, May 28). Macroprudential Policy in a Microprudential World. Symposium on Asian Banking and Finance, Singapore.

Yellen, J. (2011, April 11). Retrieved from www.federalreserve.gov/newsevents/speech/yellen20110411a.htm 